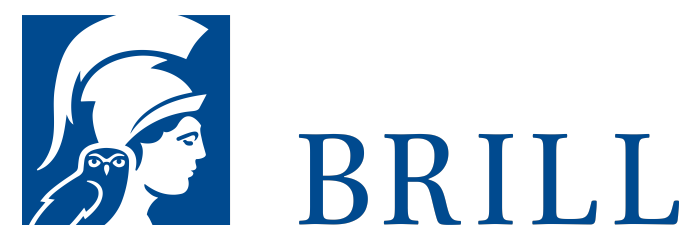

\title{
Fantasy Surgery, 1880-1930
}

With Special Reference to Sir William Arbuthnot Lane

Author: Ann Dally

In the late nineteenth century, for the first time in history, major surgery became reasonably safe. A mortality of up to $30 \%$ was considered reasonable. The living abdomen, hitherto a region as unexplored as darkest Africa, was opened up to light and to the knife in explorations not unlike those of Africa - bold, dramatic, often not too well thought out, and dangerous. Surgeons became enthusiastic - some of them wildly so. The subsequent period has been called 'the adolescence of surgery'. It included major surgery, often on the abdomen, done for psychiatric symptoms. Ovaries and wombs were removed and other organs hitched up higher inside the abdomen in an attempt to cure hysteria, neurasthenia or depression. This book is about the development and effect of some of these operations and about one of the period's most distinguished surgeons, Sir William Arbuthnot Lane. He was internationally famous in three fields of surgery (facial, mastoid and abdominal), then became deeply involved in removing colons - thought to be the 'sink' of the body and the source of dangerous infection.

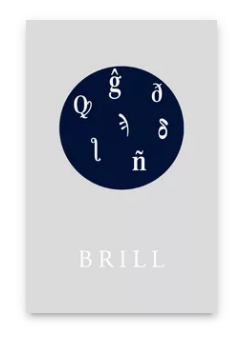

Pages: viii, 359 pp.

Language:

English

Subjects:

History of

Medicine,

History, Modern

History, History,

Contemporary

History, History

Publisher: Brill

Series:

Clio Medica

Online, Volume:

38

Clio Medica,

Volume: 38

E-Book (PDF)

Released online:

29 Jan 2020

ISBN: 978-90-

04-41847-9

List price

USD $\$ 199.00$

Hardback

Publication date:

o1 Jan 1996

ISBN: 978-90-

420-0026-1

List price

USD \$188.oo 
For more information see brill.com

Paperback

Publication date:

o1 Jan 1996

ISBN: 978-90-

Order information: Order online at brill.com

420-0oo9-4

+44330 3330049 | customerservices@brill.com

List price

Submission information: brill.com/authors

USD $\$ 51.00$

Titles published by Brill | Fink, Brill | mentis or Brill | Schöningh:

+49(o)715413279216| brill@brocom.de 